\title{
THE EFFECTS OF INTERNAL MARKETING ACTIVITIES ON THE SATISFACTION AND PERFORMANCE OF SALESPEOPLE
}

\author{
DOI: 10.17261/Pressacademia.2018.958 \\ JBEF- V.7-ISS.3-2018(9)-p.309-318
}

\author{
H. Nur Basyazicioglu ${ }^{1}$, M. Sukru Akdogan ${ }^{2}$ \\ ${ }^{1}$ Erciyes University, Faculty of Economics and Administrative Sciences, Management Department, Kayseri, Turkey. \\ nur@erciyes.edu.tr, ORCID: 0000-0001-5076-6870 \\ ${ }^{2}$ Erciyes University, Faculty of Economics and Administrative Sciences, Management Department, Kayseri, Turkey. \\ akdogans@erciyes.edu.tr, ORCID: 0000-0001-6811-706X
}

Date Received: August 8, 2018

Date Accepted: September 24, 2018

To cite this document

Basyazicioglu, H. N., Akdonan, M. S. (2018). The effects of internal marketing activities on the satisfaction and performance of salespeople. Journal of Business Economics and Finance (JBEF), V.7(3), p.309-318.

Permemant link to this document: http://doi.org/10.17261/Pressacademia.2018.958

Copyright: Published by PressAcademia and limited licenced re-use rights only.

\begin{abstract}
Purpose- This study firstly aims to explore the organization of business's implementation of internal marketing activities toward their salesforce and the determinants of job satisfaction of sales personnel. Secondly, it aims to investigate the relationship among internal marketing activities, job satisfaction, and perceived performance of the sales team.

Methodology- A face-to-face questionnaire was given to 158 sales personnel employed in malls. The collected data was examined by confirmatory factor analysis and path analysis.

Findings- It is understood that enterprises in the retail sector have done internal marketing activities such as education, communication, internal market research, and incentives. It is seen that the satisfaction of the employees is related to job qualification, colleagues, corporate image, and financial situation. In the second part of the research, it is understood that the satisfaction level of employees affects their performance. Finally, the study displays that there is a positive relationship between internal marketing activities and employees' performance

Conclusion- This study shows that internal marketing activities have both direct and indirect effects on the performance of employees.
\end{abstract}

Keywords: Internal marketing, salespeople, satisfaction, performance, path analysis.

JEL Classification: M12, M30, M31

\section{INTRODUCTION}

Marketing activities in businesses, which have a customer-focused marketing approach, are based on two pillars, namely satisfaction of customers and the continuity of relationship established with the customers. It has been understood that with a highly competitive environment, that it is not enough for customers' satisfaction to provide them with reasonable prices for products in line with their wishes and needs.

Being mindful of acquiring new customers is a costlier strategy than retaining current customers. Businesses have searched for different ways to develop long-term relationships by satisfying existing customers. For this reason, researchers have been trying to identify the factors that affect customer satisfaction. Among these factors, service quality is seen in the forefront (Parasuraman et al., 1988). It is observed, especially in service sectors such as education, tourism, and health that the service quality of the employees has an important influence on customer satisfaction. This is because employees have direct contact with customers in these sectors (Fortenberry and McGoldrick, 2016; Sohail and Jang, 2017; Walter et al., 1994). Research indicates that consumers evaluate the quality of services based on ten different characteristics. These are namely physical conditions, reliability, sensitivity, communication, credibility, safety, competence, kindness, understanding, and accessibility (Parasuraman et al., 1985). When these elements of service quality are carefully examined, it is understood that two factors especially affect perception of the service quality of customers. These are the knowledge of employees about the products they sell and the attitudes of employees towards customers, colleagues, and the institution. This is why 
businesses have begun to pay more attention to issues related with employment, training, and motivation of employees in order to satisfy their targeted customers (Fortenberry and McGoldrick, 2016). These activities, which are implemented by the enterprises, are considered as internal marketing and they play an important role on the performance of the enterprises (Nyasha et al., 2015).

There are many studies investigating the implementation of internal marketing activities in the service sector (Fortenberry and McGoldrick, 2016; Sohail and Jang, 2017; Walter et al., 1994; Nyasha et al., 2015; Caruna and Calleya, 1998) since the service cannot be separated from the employee who performs it (Parasuraman et al., 1988). However, there have been few studies on internal marketing focusing on the salespeople, who communicate directly with customers, inform, and persuade them to buy (Berry et al., 1976; Bell et al., 2004). For this reason, this study aims to contribute to the related literature.

Considering the significant influence of sales staff on business performance and customer satisfaction, the main purpose of this study is to examine the effect of internal marketing activities on both the job satisfaction and performance of the sales team. For this purpose, both organizations' implementation of internal marketing activities toward their sales teams and the factors affecting the satisfactions of the salespeople are firstly analyzed by confirmatory factor analysis in order to determine their sub-dimensions. Then, the relationship among internal marketing activities, employee satisfaction, and perceived performance are analyzed with path analysis.

\section{LITERATURE REVIEW}

Berry, Hensel, and Burke (1976) are the first researchers who investigated the influence of internal marketing activities on the degree of customers' satisfaction. Their study contributed the conception of internal marketing into literature. Their study implies that customers are divided into two parts, internal and external. According to this separation, buyers of products are referred to as external customers whereas the employees of the company at all levels are defined as internal customers. Internal customers also have particular needs and desires, just as external customers. Therefore, businesses are able to satisfy external customers thanks to fulfilling the needs and desires of their internal customers with internal marketing activities.

In related literature, many scholars have defined internal marketing differently since its first explanation, and they have studied it in different dimensions (Walter et al.,1994; Varey, 1995; Bell et al., 2004). For instance, Gummesson (1995) defined internal marketing as the implementation of the same marketing activities, which the organization applies to its external customers, towards its employees. Whereas, Kotler and Keller (2006) defined internal marketing as a strategy which covers the education and motivation of employees, with the aim of customers' satisfaction.

In the broadest sense, internal marketing is defined as a set of activities that directs current employees to ensure external customer satisfaction in order to enable the business to realize its mission by organizing its activities to provide internal and external customer satisfaction by making use of education, communication, and motivation of employees (Yapraklı and Özer, 2001).

As the definition of internal marketing implies, the scope of such activities is so broad that it prompts questions about the specific department of the organizations in charge of internal marketing activities. It is stated that internal marketing activities are closely related to the marketing department because of the definition of employees as internal customers and the business activities, which ensure the needs and requests of the internal customers as well as those of the external customers (Ahmed and Rafiq, 1995). Hence the interested field of marketing departments widen from external customer to internal customers. This means the marketing department's responsibilities in the business have increased (Collins and Payne, 1991). Additionally, internal marketing activities are regarded as the missing half of marketing (Piercy and Morgan, 1991). Therefore, it is thought that marketing activities for both internal and external customers are important in terms of the completeness of marketing strategies.

Internal marketing activities are too crucial and important to leave the entire responsibility to only marketing departments. (Ewing and Caruana, 1999). Having reviewed the literature, it is seen that internal marketing activities are examined on the basis of internal market research and different applications of business activities such as education, communication, rewards and support of leadership (Sohail and Jang, 2017; Huang and Rundle-Thiele, 2014; Thomson and Hecker, 2001; Paraskeves, 2001). Internal marketing is not totally under responsibility of a sole department in an organization. The department of human resources arguably has a congruent responsibility of internal marketing activities, since internal marketing includes the activities of employing, training, and career planning of qualified workers. (Joseph, 1994).

Internal marketing has a noteworthy relationship with such activities as increasing the quality of service and standardization of service quality. In addition to departments of marketing and human resources, considering the effect of employees' performance on service quality, it is seen that internal marketing is closely related to total quality management (Nyasha et al., 2015). Therefore, internal marketing is suggested to be a contributor to the establishment of quality culture in 
organizations (Gummesson, 1987). Instead of leaving the entire responsibility of internal marketing activities to only one department, it is a more accurate approach for businesses to consider internal marketing as a kind of strategic partnership among the human resources management, marketing, and total quality management departments, (Rafiq and Ahmet, 1993).

\section{Internal Marketing and Satisfaction of Internal Customers}

Like other marketing activities, internal marketing surely aims to satisfy external customers too. The difference between other marketing activities and internal marketing activities arises from the methods chosen in order to achieve the target. Within the scope of internal marketing strategy, business organizations focus on their employees rather than their customers (Bailey et al., 2016). Enterprises believe that if they fulfill the needs and wishes of their internal customers and satisfy them, they can orient their employees towards the satisfaction of external customers, so that the businesses can achieve their mission. For this reason, enterprises aim to increase their employees' performances through internal marketing activities such as education, communication, internal market research, and incentives.

In order to increase performance, employees must first be competently informed about their work responsibilities so that they may completely accomplish their tasks. Training is the first possible method to increase employees' occupational abilities. Training affects the performance of employees (Lee et al., 2012). Thus, organizations get a competitive advantage by training their employees (Tseng, 2009). For this reason, education is considered as first among all the priorities in internal marketing. Employees regard business training as an indicator of the value and importance given them by their organizations. In addition, employees evaluate training activities as an opportunity to improve their occupational skills. Therefore, training has been discussed to have a positive impact on the satisfaction of internal customers (Navimipour and Zareie, 2015).

Communication within an organization is the second important component of internal marketing strategy. Communication is an important tool to transfer information related with the needs and desires of employees to the upper management. Thus, an effective communication within an organization makes employees feel confident and generates commitment to the organization (Mishra et al., 2014). Because one of the most significant topics of internal marketing is to satisfy internal customers by determining and meeting their needs and desires, an effective and strong communication within an organization facilitates the goal of internal marketing strategy. Hence, it is predicted that organizations can satisfy their internal customers with effective communication (Men, 2014).

Internal market research is another activity within the internal marketing strategy. Internal market research aims to improve the quality of products and services by taking into consideration the opinions of employees. Assuming that the employees have the same expectations as external customers, the evaluation of the performance of the business by the internal customers is supposed to give guidance to businesses related to the satisfaction of external customers (Paraskevas, 2001). For this reason, it has been observed that the marketing activities implemented by the opinions of employees are more successful (Sohail and Jang, 2017). Aside from practicing successful marketing activities, conducting internal market research and getting the opinions of employees makes them feel that they are contributing to the decision-making process in the organizations. Therefore, internal market research does indeed affect internal customer satisfaction (Huang and Rundle-Thiele, 2014).

In addition to these business applications, businesses encourage their employees to increase their job performance with financial incentives such as a higher salary, extra payments and premiums, and with emotional incentives such as choosing an employee of the month, hanging photos of selected employees on a workplace wall, and giving plaques to employees. These kinds of internal marketing activities seem to both motivate employees and increase employee satisfaction (Nyasha et al., 2015). Thus, internal marketing activities such as training, communication, internal market research, and incentives are thought to have a significant impact on internal customer satisfaction and employee performance.

\section{Internal Marketing and Sales Personnel}

In literature, the efficiency of internal marketing activities evaluated are concentrated in service sectors such as tourism (Huang and Rundle-Thiele, 2014; Nyasha et al., 2015), education (Alghamdi, 2016; Hemsley-Brown and Goonawardana, 2007), and health (Fortenberry and McGoldrick, 2015; Peltier et al., 2008), since service is one sector, where workers have become a part (Caruna and Calleya, 1998). However, it is proposed that internal marketing activities also affect businesses in the retail sector (Berry et al., 1976).

In the retail sector, stores are important selling points where businesses display their products for consumers to examine and buy. It is implied that sales staff working in these stores are a bridge between business and customers and consequently they undertake sales activities (Yükselen, 2010). These employees are also internal customers. 
Examining the purchasing behaviors of consumers, it is understood that the purchasing decision of the consumers is determined by store features such as appearance, location, the arrangement of vitrines, internal decorations, the music that is played, the atmosphere, and cleanliness (İslamoğlu and Altunışık, 2009). Furthermore, it must be added that the assessment of information is related with product quality, price, delivery conditions, and payment facilities (Karafakıoğlu, 2012). However, the most important factor leading consumers to buy something during their visit and to leave the store in a satisfactory manner is the physical, visual, and behavioral characteristics of the sales personnel (i̇slamoğlu and Altunışık, 2009). This is why the performance of sales personnel plays a key role in business performance and customer satisfaction. Businesses aim to increase the knowledge and skills of their sales team by educating sales staff in order to improve their sales force performance and to satisfy their customers (Yükselen, 2010). At the same time, business organizations have an interest in learning the information employees obtain from consumers via communication. Furthermore, businesses benefit from salespeople's experience in improving business performance by doing internal market research. Finally, businesses encourage their salespeople with financial and emotional incentives to ensure that their employees work more willingly to achieve their sales targets (İslamoğlu and Altunışık, 2009).

Based on the view that the performance of salespeople has a significant influence on customer satisfaction and business performance in the retail sector, businesses undertake internal marketing activities for their sales force to have a positive impact on both the satisfaction level and the performances of their employees. This positive effect is supposed to raise the customer satisfaction level and therefore, also the performance of the company. Within this theoretical framework, this study aims to test the hypotheses given below:

$\mathrm{H}_{1}$ : Internal marketing activities have a positive effect on the satisfaction of salespeople.

$\mathrm{H}_{2}$ : Satisfaction of salespeople has a positive effect on their perceived performance.

$\mathrm{H}_{3}$ : Internal marketing activities have a positive effect on their perceived performance.

\section{DATA AND METHODOLOGY}

This study has two main goals. Firstly, it aims to investigate businesses' implementation of internal marketing activities for salespeople in the retail sector and to explore the determinants that factor in the satisfaction of these employees. Secondly, this study tries to comprehend the relationship among internal marketing, job satisfaction of salespeople, and the perceived performance of these employees. Hence, the research begins with determining sub-dimensions of internal marketing and satisfaction of employees with a confirmatory factor analysis. Then, the relationship among internal marketing, satisfaction and perceived performance of salesforce is to be examined with path analysis. In accordance with the objectives of the study, the research model, which is used to test the hypothesis of this study, is shown in Figure 01 below.

Figure 1: Research Model

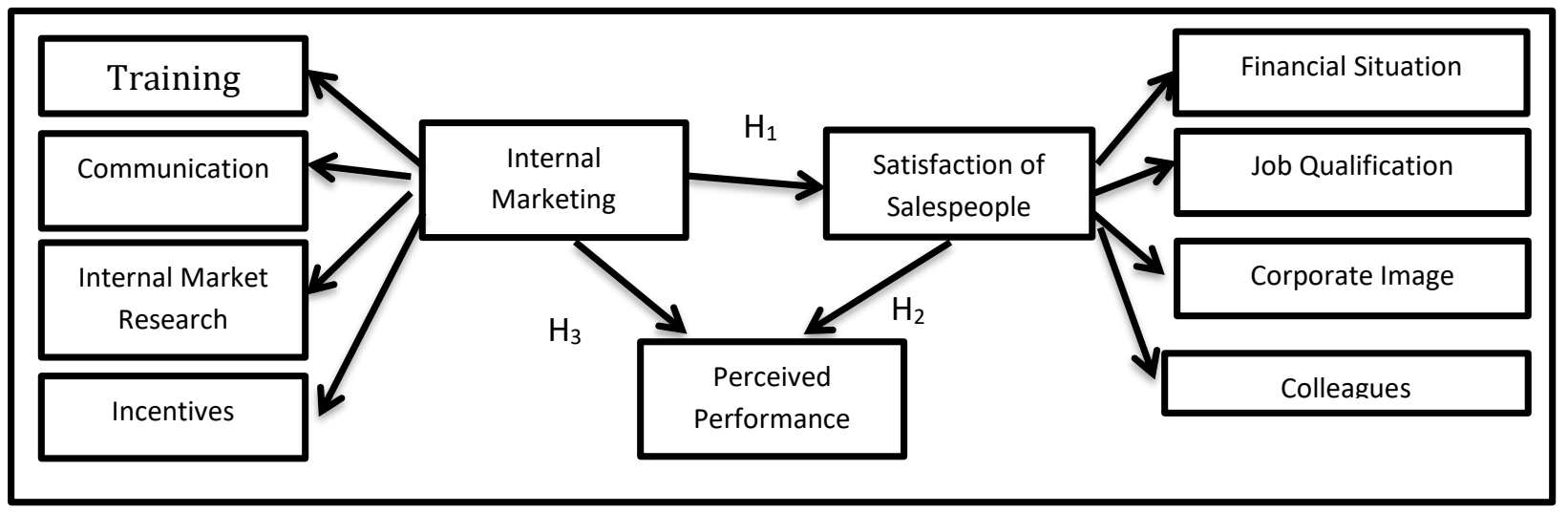

The research model, shown in Figure 01, has its foundation in literature (Sohail and Jang, 2017; Huang and Rundle-Thiele, 2014; Bell et al., 2004; Nyasha et al., 2015; Gummesson, 1987; Fortenberry and McGoldrick, 2016; Panigyrakis and Theodoridis, 2009). 


\section{Data Collections and Sampling Method}

In this research, the sample was determined based on convenience sampling. Convenience sampling is a non-probability sampling technique and it is conducted according to the judgement of the researcher. It is thought that organizations with well-known brands having completed construction of their corporate identity are assumed to give more attention to internal marketing. Therefore, the sample of this research consists of salespeople working at organizations that have wellknown brands in the retail sector. It is not possible to reach each salesperson within the time and financial limitations of research. Additionally, it is known that almost all almost all organizations with a well-known brand in retail sectors have stores in big malls. Consequently, it was decided to conduct the survey, based on convenience sampling, at three big malls in Kayseri.

Data collection was completed with 158 surveys. Among these participants, 53\% of the respondents were female and $47 \%$ were male. $43 \%$ of salespeople were under the age of 25 and $50 \%$ were between the ages of 26 and 33 . When age statistics are examined, it is understood that salespeople working at shopping malls are young and are still at the beginning of their careers. $52.5 \%$ of the participants were high school and/or primary school graduates. In terms of income distribution, only $2.5 \%$ of the salespeople participating in the survey receive higher than the minimum wage, $70.9 \%$ earn minimum wage, and $26.6 \%$ of them earn below the minimum wage. The main reason for the low salaries of the sales staff is that young people are either employed part-time or hourly in shopping malls.

\section{Measures}

Data collected consisted of four main parts: a "5-point Likert Type Scale" was used for the first three parts of the survey. The first part, consisting of 15 questions was designed to evaluate internal marketing activities based on previous research (Money and Foreman, 1996). The second part, with 18 questions, was calculated to measure the satisfaction of employees based on literature (Yazıcıoğlu, 2010). The third part included 9 questions to measure the perceived performance of salespeople. The last section consisted of demographic questions.

\section{FINDINGS AND DISCUSSIONS}

Before analyzing the data derived from the sample, a reliability analysis was performed to determine whether the data was meaningful as a whole. According to this analysis, the values of Cronbach's Alpha for three scales are shown in Table 1.

\section{Table 1: Reliability Statistics of Scales}

\begin{tabular}{|l|l|}
\hline Scales & Cronbach's Alpha \\
\hline Internal Marketing & 0.934 \\
\hline Satisfaction of Salespeople & 0.942 \\
\hline Perceived Performance & 0.961 \\
\hline
\end{tabular}

As shown in Table 1 above, all values of Cronbach's Alpha are larger than 0.8 . This indicates that the scales are reliable. In addition to reliability analysis, the Hoteling $\mathrm{T}^{2}$ Tests for all scales were significant at 0.0001 . These statistics indicate that the difference between the data is statistically significant, and it is concluded that the data is suitable for use in various analysis.

The adequacy of the sample size and the compliance of the data to factor analysis was first analyzed by KMO and Bartlett Test. The value of the KMO analysis for internal marketing was 0.934 and the value of the KMO analysis for satisfaction of salespeople was 0.942 . The Bartlett test result of both scales was significant at 0.0001 . Thus, it is understood that the relationship between the variables in each scale is meaningful and these scales are compatible with the factor analysis. Two main types of factor analysis exist namely, Explanatory Factor Analysis (EFA) and Confirmatory Factor Analysis (CFA). EFA is generally used when researchers have a general idea about a research topic, but they have not predicted how many factors exist or which variables will most likely load onto which factor so that they have not composed specific hypotheses CFA is used in cases where researchers have prior knowledge about the factors (Hurley et al., 1997). Since a review of internal marketing literature shows that researchers divide internal marketing strategies into different activities such as of training, communications, market research, and financial and psychologic incentives, in this research, the internal marketing activities of the enterprises and the satisfaction of salespeople were divided into groups by confirmatory factor analysis. Table 2 displays the results of the confirmatory factor analysis. 


\section{Table 2: Confirmatory Factor Analysis for Internal marketing and Satisfaction of Salespeople}

\begin{tabular}{|c|c|c|c|}
\hline Latent Variables for Internal Marketing & \begin{tabular}{|l|} 
Std. Path \\
Values
\end{tabular} & $\begin{array}{l}\text { t- } \\
\text { Test }\end{array}$ & $\mathbf{R}^{2}$ \\
\hline \multicolumn{4}{|l|}{ Factor 1: Training } \\
\hline The organization prepares its employees to perform well in their jobs. & 0.78 & 0.84 & 0.57 \\
\hline The organization thinks development of employees' skill and knowledge as an investment & 0.76 & 0.61 & 0.48 \\
\hline The skill and knowledge of employees improve in job processes. & 0.72 & 0.74 & 0.56 \\
\hline The organization teaches employees why they should do their job besides how. & 0.72 & 0.67 & 0.48 \\
\hline The organization trains its employees beyond education. & 0.87 & 1.29 & 0.6 \\
\hline The employees are trained appropriately to do their jobs in the organization. & 0.83 & 1.08 & 0.58 \\
\hline \multicolumn{4}{|l|}{ Factor 2: Incentives } \\
\hline $\begin{array}{l}\text { The organization's performance measurement and reward systems encourage employees to } \\
\text { work together. }\end{array}$ & 0.74 & 0.78 & 0.42 \\
\hline $\begin{array}{l}\text { The organization often measures and rewards the performance of employees who contribute } \\
\text { to the organization's vision. }\end{array}$ & 0.98 & 2.46 & 0.7 \\
\hline Employees who provide excellent service at the organization are rewarded for their efforts. & 0.84 & 0.12 & 0.52 \\
\hline The organization is flexible enough to supply the different needs of employees. & 0.71 & 0.32 & 0.46 \\
\hline \multicolumn{4}{|l|}{ Factor 3: Internal Market Research } \\
\hline $\begin{array}{l}\text { The organization gathers information from its employees to improve the duties of employees } \\
\text { and improve the organization strategy. }\end{array}$ & 0.72 & 0.9 & 0.43 \\
\hline The organization gives opportunity to new thoughts and behaviors & 0.93 & 1.91 & 0.67 \\
\hline The suggestion made by employees about the business is considered. & 0.8 & 0.29 & 0.54 \\
\hline \multicolumn{4}{|l|}{ Factor 4: Communication } \\
\hline The organization provides a vision for their employees to believe. & 0.83 & 0.71 & 0.55 \\
\hline The organization conveys its vision to its employees in an appropriate way. & 0.75 & 1.86 & 0.64 \\
\hline The organization transmits the importance of service roles to the employees. & 0.84 & 1.94 & 0.52 \\
\hline Communication with employees is very important in organization. & 0.71 & 0.18 & 0.29 \\
\hline Latent Variables for Satisfaction of Salespeople & \begin{tabular}{|l|} 
Std. Path \\
Values
\end{tabular} & $\begin{array}{l}\text { t- } \\
\text { Test }\end{array}$ & $\mathbf{R}^{2}$ \\
\hline \multicolumn{4}{|l|}{ Factor 1: Job Qualification } \\
\hline The responsibilities and authorization in the job are determined clearly. & 0.83 & 0.82 & 0.58 \\
\hline I do a job that fits the skills and talents. & 0.75 & 0.56 & 0.49 \\
\hline My job contributes into my personal improvement. & 0.71 & 0.06 & 0.45 \\
\hline My job meets my job expectations. & 0.86 & 0.2 & 0.53 \\
\hline I can use my creativity in my job. & 0.66 & 0.41 & 0.32 \\
\hline \multicolumn{4}{|l|}{ Factor 2: Colleagues } \\
\hline My colleagues help me in case of a problem. & 0.82 & 0.8 & 0.57 \\
\hline I have a good relationship with my colleagues. & 0.82 & 1.57 & 0.63 \\
\hline My colleagues specialize in their job. & 0.82 & 1.06 & 0.59 \\
\hline I feel as a team member when I am with my colleagues & 0.83 & 1.45 & 0.62 \\
\hline
\end{tabular}




\begin{tabular}{|c|c|c|c|}
\hline Factor 3: Corporate Image & & & \\
\hline I regard working in the organization as a source of prestige. & 0.86 & 1.97 & 0.69 \\
\hline I think the organization has a good reputation in its sector. & 0.78 & 0.78 & 0.59 \\
\hline \multicolumn{4}{|l|}{ Factor 4: Financial Situation } \\
\hline All employees are equally benefiting from the resources of organizations. & 0.82 & 0.96 & 0.43 \\
\hline I believe I receive the salary I deserved. & 0.98 & 3.49 & 0.76 \\
\hline I am satisfied with the extra payment of the organization. & 0.99 & 3.5 & 0.76 \\
\hline $\begin{array}{l}\text { I am satisfied with the sale opportunity of organization which are provided only to employees } \\
\text { of organization }\end{array}$ & 0.96 & 1.28 & 0.6 \\
\hline I am satisfied with the gift given by the organization. & 0.97 & 2.72 & 0.7 \\
\hline
\end{tabular}

As shown in Table 2 above, internal marketing activities are divided into four factors, namely training, incentives, internal market research, and communication. It is understood that the satisfaction of the sales staff is also divided into four factors as satisfaction from the job qualification, colleagues, corporate image, and financial situation.

When Table 2 is examined, it is seen that the standardized path values and the determination coefficients $\left(R^{2}\right)$, which determine the relationship between expressions and latent variables, are high. Although these results provide information that the expressions are distributed correctly in the factors, it is necessary to look at the results of the $\chi 2$ test and the fit indices of the analysis to evaluate the statistical significance of the confirmatory factor analysis. The $\chi 2$ test is found to be significant at the level of 0.0001 , taking the value of 1370.61 in 783 degrees of freedom. When examining the indices that assess the statistical significance of the confirmatory factor analysis, the value of RMSEA is 0.069 , the value of SRMR is 0.071 , the values of $\mathrm{CFI}, \mathrm{NCFI}$ and NNFI are 0.97 , and the value of NFI are 0.94 . These statistics indicate that confirmatory factor analysis has a good fit. Thus, it is found appropriate to continue the analysis with these factors.

After analyzing internal marketing activities and the satisfaction of salespeople in detail with confirmatory factor analysis, whether there are statistically significant relationships among internal marketing activities, satisfaction of salespeople, and their perceived performance were determined by path analysis. The results of path analysis are shown in Table 3.

Table 3: The Relationship Between Factors and The Value of Paths

\begin{tabular}{|l|l|l|l|}
\hline The relationship between factors & Std. Path values & t- Test & $\mathbf{R}^{\mathbf{2}}$ \\
\hline Internal Marketing- Training & 0.93 & 10.17 & 0.87 \\
\hline Internal Marketing- Communication & 0.98 & 10.33 & 0.95 \\
\hline Internal Marketing- Incentives & 0.92 & 8.25 & 0.84 \\
\hline Internal Marketing- Internal Market Research & 0.89 & 8.46 & 0.79 \\
\hline Satisfaction of Salespeople- Qualification of Job & 0.92 & 9.79 & 0.84 \\
\hline Satisfaction of Salespeople- Colleagues & 0.9 & 9.56 & 0.81 \\
\hline Satisfaction of Salespeople- Corporate Image & 0,91 & 11.09 & 0.83 \\
\hline Satisfaction of Salespeople- Financial Situation & 0,68 & 6.74 & 0.46 \\
\hline Internal Marketing-Satisfaction of Salespeople & 0,8 & 9.54 & 0.64 \\
\hline Internal Marketing- Perceived Performance & 0,34 & 2.75 & 0.38 \\
\hline Satisfaction of Salespeople- Perceived Performance & 0,34 & 2.8 & 0.42 \\
\hline
\end{tabular}

When Table 3 is examined, it is seen that there are positive and strong correlations between the factors and t-test values that test these correlations are significant at level 0.0001. Thus, it is understood that all relations shown in Figure 1 are meaningful. However, the validity of the research model shown in Figure 01 as a whole is understood after the evaluation of the $\chi 2$ test and model fit indices. Therefore, when the $\chi 2$ test is evaluated, it is seen that the $\chi 2$ test has a value of 2087.96 in 857 degrees of freedom and this value is significant at level 0.0001 . According to the model's fit indices, RMSEA is found to be 0.096 , SRMR is 0.076 , NFI is 0.93 , and NNFI and CFI are 0.96. Other fit indices, except for the RMSEA value, 
indicate that the model has good fit. The RMSEA value shows that the model is an acceptable model. Thus, the research model is accepted as a whole.

As for the validity of the t-test values evaluating the acceptance of the research model and measuring the significance of the relationships between the variables in the research model, all hypotheses tested in the study are accepted. In terms of the relationship focused in the first hypothesis, displayed on Table 3, the standardized path value between internal marketing and satisfaction of salespeople is 0.8 . It means that there is a positive and strong correlation between these two variables. In addition, by looking at the equation of structural equation that characterizes the relationship between these two variables, it is seen that the coefficient of determination is 0.64 . This statistic indicates that $64 \%$ of salespeople's satisfaction can be explained by internal marketing activities. Thus, it is understood how important internal marketing activities are in terms of the satisfaction of sales staff.

When Table 3 is examined together with the relationship between satisfaction and perceived performance of salespeople tested in the second hypothesis, it is seen that there is a positive correlation between these two variables. In accordance with the structural equality equation for these variables, the determination coefficient is 0.42 . It means that $42 \%$ of the performance is related to the satisfaction of salespeople. This statistic confirms that the more the employees are satisfied, the better they perform.

Finally, when the relationship between internal marketing and perceived performance in the third hypothesis is evaluated, it is seen that there is a positive correlation between the two variables. The coefficient of determination in the structural equality equation of the relationship between variables is 0.38 . It displays that $38 \%$ of salespeople's performance can be explained by internal marketing activities. Thus, it is understood that internal marketing activities have a strong direct effect on the satisfaction of employees and it has both a direct and an indirect effect on the perceived performance, by affecting the satisfaction of the salesperson

\section{CONCLUSION}

This study examined internal marketing activities executed by enterprises and the effect of these activities on the satisfaction and performance of salespeople in the retail sector. In accordance with this purpose, 158 randomly selected salespeople working in three big shopping malls in Kayseri were given a face-to-face survey in order to gather data within the time and financial constraints of this research. The data collected from the sales staff were analyzed with a two-step process. In the first step, it was planned to reveal the sub-dimensions of the internal marketing activities and the satisfactions of the sales staff with confirmatory factor analysis. As a result of confirmatory factor analysis, it was determined that the internal marketing activities of the enterprises are divided into four factors, education, communication, internal market research, and incentives. It has been seen that these results are consistent with the research related to internal marketing activities in the service sector. (Lee, 2012; Tseng, 2009; Mishra et al. 2014; Paraskevas, 2001; Huang and Rundle-Thiele, 2014). However, this study has differed from other studies by focusing on the retail sector. Thus, it has been understood that the internal marketing activities in the service sector are also used in the retail sector. Businesses have motivated their sales team to improve their knowledge and skills in order to encourage their employees to perform better.

In addition to internal marketing activities, when the satisfactions of salespeople were examined with a confirmatory factor analysis, four sub-dimensions of satisfaction of employees were retained, namely job qualification, colleagues, corporate image, and financial situation. It has been noteworthy to mention that the employees' satisfaction is generally discussed as a whole and its sub-dimensions are not examined in literature (Alghamdi, 2016; Bernhardt et al., 2000; Huang and RundleThiele, 2014). For this reason, it believed that this study differs from other studies existing in the literature since it examines the factors affecting the satisfaction of the sales staff.

In the second part of the study, the relationship between internal marketing activities, satisfaction, and perceived performance of salespeople were examined with path analysis. As a result of the path analysis, it was determined that there is a strong positive relationship between internal marketing activities and the satisfactions of salespeople. Thus, similar to the service sector (Sohail and Jang, 2017), it is understood that internal marketing activities have affected employee satisfaction positively in the retail sector. Furthermore, as a result of the path analysis, it is seen that there is a positive relationship between satisfaction and the perceived performance of salespeople. Therefore, it is understood that the satisfaction level of employees affects their performance. Finally, this study displays that there is a positive relationship between internal marketing activities and employees' performance. Parallel to the results of the research on internal marketing activities in different sectors (Panigyrakis and Theodoridis, 2009), it is seen that internal marketing activities affect employees' performance in the retail sector as well. However, unlike other studies, this study has concluded that internal marketing activities have both direct and indirect effects on the performance of the employees attributable to affecting the satisfaction of the employees. 
It is not possible to generalize the results of this study in order to cover other sectors since the work was only done on employees, who are employed as sales personnel in shopping malls within Kayseri. Nevertheless, what makes this study important is that it reveals factors of internal marketing activities and employee satisfaction. Moreover, this study presents that internal marketing activities are important not only in the service sector but also in the retail sector.

It is predicted that if businesses satisfy their internal customers with internal marketing activities, that the employee turnover rate will decrease. In addition, employees can own part of the business and thus feel trust and loyalty to the business. Hence, employees provide better service to the customers and this gives rise to the satisfaction of external customers as well. For this reason, this study can provide a starting point for future work to examine the effect of internal marketing activities on turnover rate and loyalty of employees.

\section{REFERENCES}

Ahmed, P. K., Rafiq, M. (1995). The role of internal marketing in the implementation of marketing strategies. Journal of Marketing Practice: Applied Marketing Science, 1(4), 32-51.

Alghamdi, A. A. (2016). The impact of the service quality as a mediating variable on the relationship between internal marketing policies and internal customer satisfaction: an empirical study at Taif University. Journal of Marketing Management, 4(1), $104-124$.

Bailey, A. A., Albassami, F., Al-Meshal, S. (2016). The roles of employee job satisfaction and organizational commitment in the internal marketing-employee bank identification relationship. International Journal of Bank Marketing, 34(6), 821-840.

Bell, S. J., Mengüç, B., Stefani, S. L. (2004). When customers disappoint: a model of relational internal marketing and customer complaints. Journal of the Acadethe of marketing science, 32(2), 112-126.

Bernhardt, K. L., Donthu, N., Kennett, P. A. (2000). A longitudinal analysis of satisfaction and profitability. Journal of business research, 47(2), 161-171.

Berry, L. L., Hensel, J. S., Burke, M. C. (1976). Improving retailer capability for effective consumerism response. Journal of retailing, 52(3), 314.

Caruana, A., Calleya, P. (1998). The effect of internal marketing on organisational commitment among retail bank managers. International Journal of bank marketing, 16(3), 108-116.

Collins, B., Payne, A. (1991). Internal marketing: a new perspective for HRM. European Management Journal, 9(3), $261-270$.

Ewing, M. T., Caruana, A. (1999). An internal marketing approach to public sector management: the marketing and human resources interface. International Journal of Public Sector Management, 12(1), 17-29.

Fortenberry Jr, J. L., McGoldrick, P. J. (2016). Internal marketing: a pathway for healthcare facilities to improve the patient experience. International Journal of Healthcare Management, 9(1), 28-33.

Greene, W. E., Walls, G. D., Schrest, L. J. (1994). Internal marketing: the key to external marketing success. Journal of Services marketing, $8(4), 5-13$.

Gummesson, E. (1987). Using internal marketing to develop a new culture-the case of Ericsson quality. Journal of Business ve Industrial Marketing, 2(3), 23-28.

Hales, C. (1994). 'Internal Marketing'as an approach to human resource management: a new perspective or a metaphor too far?. Human Resource Management Journal, 5(1), 50-71.

Hemsley-Brown, J., Goonawardana, S. (2007). Brand harmonization in the international higher education market. Journal of business Research, 60(9), 942-948.

Huang, Y. T., Rundle-Thiele, S. (2014). The moderating effect of cultural congruence on the internal marketing practice and employee satisfaction relationship: an empirical examination of Australian and Taiwanese born tourism employees. Tourism Management, 42, 196206.

Hurley, A. E., Scandura, T. A., Schriesheim, C. A., Brannick, M. T., Seers, A., Vandenberg, R. J., Williams, L. J. (1997). Exploratory and confirmatory factor analysis: guidelines, issues, and alternatives. Journal of organizational behavior, 667-683.

İslamoğlu, A. H., Altunışık, R. (2009). Satış ve satış yönetimi (Gözden geçirilmiş 2. Baskı). Adapazarı: Sakarya Yayıncılık.

Joseph, W. B. (1996). Internal marketing builds service quality. Marketing Health Services, 16(1), 54-59.

Karafakıoğlu, M. (2006). Örnek olaylarla satış yönetimi (4. Basım). İstanbul: Literatür Yayınları.

Kotler, P., Keller K. L. (2006). Marketing management (12th Edition). New Jersey: Pearson Prentice Hall.

Lee, S. M., Lee, D., Kang, C. Y. (2012). The impact of high-performance work systems in the health-care industry: employee reactions, service quality, customer satisfaction, and customer loyalty. The Service Industries Journal, 32(1), 17-36 
Men, L. R. (2014). Strategic internal communication: transformational leadership, communication channels, and employee satisfaction. Management Communication Quarterly, 28(2), 264-284.

Money, A. H., Foreman, S. (1996). The measurement of internal marketing: a confirmatory case study. Journal of Marketing Management, $11(8), 755-766$.

Navimipour, N. J., Zareie, B. (2015). A model for assessing the impact of e-learning systems on employees' satisfaction. Computers in Human Behavior, 53, 475-485.

Nyasha, M., Vision, T., Faith, M. R. (2015). Impact of internal marketing on organisational performance. International Journal of Innovative Research and Development, 4(5), 333-340.

Panigyrakis, G. G., Theodoridis, P. K. (2009). Internal marketing impact on business performance in a retail context. International Journal of Retail ve Distribution Management, 37(7), 600-628.

Paraskevas, A. (2001). Exploring hotel internal service chains: a theoretical approach. International Journal of Contemporary Hospitality Management, 13(5), 251-258.

Paraskevas, A. (2001). Internal service encounters in hotels: an empirical study. International Journal of Contemporary Hospitality Management, 13(6), 285-292.

Parasuraman, A., Zeithaml, V. A.,, Berry, L. L. (1985). A conceptual model of service quality and its implications for future research. the Journal of Marketing, 41-50.

Parasuraman, A., Zeithaml, V. A., Berry, L. L. (1988). Servqual: a multiple-item scale for measuring consumer perc. Journal of retailing, 64(1), 12.

Peltier, J. W., Pointer, L., Schibrowsky, J. A. (2008). Internal marketing and the antecedents of nurse satisfaction and loyalty. Health marketing quarterly, 23(4), 75-108.

Piercy, N. F. (1995). Customer satisfaction and the internal market: marketing our customers to our employees. Journal of Marketing practice: Applied marketing science, 1(1), 22-44.

Piercy, N., Morgan, N. (1991). Internal marketing-the missing half of the marketing programme. Long range planning, 24(2), 82-93.

Rafiq, M., Ahmed, P. K. (1993). The scope of internal marketing: defining the boundary between marketing and human resource management. Journal of Marketing Management, 9(3), 219-232.

Thomson, K., Hecker, L. (2001). Value-adding communication: innovation in employee communication and internal marketing. Journal of Communication Management, 5(1), 48-58.

Tseng, S. M. (2009). A study on customer, supplier, and competitor knowledge using the knowledge chain model. International Journal of Information Management, 29(6), 488-496.

Varey, R. J. (1995). A model of internal marketing for building and sustaining a competitive service advantage. Journal of Marketing Management, 11(1-3), 41-54.

Yapraklı, Ş., Özer, S. (2001). Çağdaş pazarlamada yeni bir yaklaşim: içsel pazarlama. Pazarlama Dünyası Dergisi, (6), 58-62.

Yazıcıoğlu, i. (2010). Örgütlerde iş tatmini ve iş gören performansı ilişkisi: Türkiye ve Kazakistan karşılaştırması. Bilig, 55(1), 243-264.

Yükselen, C. (2010). Satış yönetimi (3. Baskı), Ankara: Detay Yayıncılık. 